\title{
Effect of glucocorticoids on the hexose monophosphate pathway in human rheumatoid synovial lining cells in vitro and in vivo
}

\author{
LUCILLE BITENSKY, B. CASHMAN 1 , J. J. JOHNSTONE, AND J. CHAYEN
}

From the Division of Cellular Biology, Kennedy Institute of Rheumatology, London, and the Orthopaed $\overrightarrow{\overrightarrow{i o}}$ Department, Bedford General Hospital, Bedford ${ }^{1}$

SUMMARY Human rheumatoid synovial lining cells have up to four times the capacity to oxidizi glucose 6-phosphate, the first step of the hexose monophosphate pathway, as do the nonrheumator cells. The reducing equivalents produced by this system have many significant metabolic effects. Exposure of these cells to $10^{-5} \mathrm{M}$ prednisolone in vitro, or to $6 \mathrm{mg} / \mathrm{day}$ in vivo, causes some depression of this activity in the rheumatoid synovial lining cells; less than this dose of steroid, or the administration of nonsteroidal drugs in vivo, has little or no effect. The depression of activity produce by $6 \mathrm{mg}$ /day does not bring this activity down to the value found in nonrheumatoid synoviocyte

Even though synthetic glucocorticoids, such as hydrocortisone and prednisolone, have been much used in the treatment of rheumatoid arthritis, their mode of action is not fully known. Attention has been paid to the possible beneficial effect of such steroids on lysosomes either in the inflammatory cells or in the cells of the synovial tissue because it is known that this type of steroid stabilizes the membranes of isolated lysosomes (Weissmann, 1968, 1969). Bitensky et al. (1974) showed that a sufficient concentration of $10^{-4} \mathrm{M}$ glucocorticoids applied to synovial tissue maintained in vitro produced some stabilization of the lysosomal membranes in the synovial lining cells. Moreover they showed a quantitatively similar stabilization in vivo in patients who had been receiving at least $5 \mathrm{mg}$ prednisolone a day; lower single daily doses of prednisolone had little or no effect. However, the maximum degree of stabilization achieved by even the higher concentrations of glucocorticoid was still only $30-50 \%$ of that found in the relatively normal synovial lining cells of nonrheumatoid joints.

It has also been observed (Butcher et al., 1973) that the activity of glucose 6-phosphate dehydrogenase in rheumatoid synoviocytes was three to four times greater than in the synoviocytes of nonrheuma-

Accepted for publication January 7, 1977

Correspondence to Dr. J. Chayen, Kennedy Institute of Rheumatology, Bute Gardens, Hammersmith, London W6 7DW toid synovial tissue. Because the hexose monophos phate pathway, and the reducing equivalen generated by it, subserve many functions in cellulä metabolism, the raised activity of glucose 6-phosphafie dehydrogenase, the first step in this pathwas indicated a significant difference in the metabol activity in the rheumatoid synoviocytes. Moreove there is evidence that cortisone, and steroids $\bar{\oplus}$ similar configuration, influence the production aned utilization of reducing equivalents generated glucose 6-phosphate dehydrogenase activity (Chay et al., 1974). We therefore decided to investiga whether glucocorticoids affected this abnormalig high rate of generation of NADPH, by glucoße 6-phosphate dehydrogenase activity, in huma synovial lining cells.

\section{Material}

The study was made on 13 specimens from 10 patients who had been treated either with nonsteroidal drugs or with $<5 \mathrm{mg}$ prednisolone/day; 8 specimens from 7 patients who had received $5 \mathrm{mg}$ prednisolone more each day; and 1 specimen from a patient treated with Acthar gel (Table 1). All had definite ơr classical rheumatoid arthritis according to the diagnostic criteria of the American Rheumatis政 Association (Ropes et al., 1959). The specimeo were obtained at synovectomy. All patients who had been treated with prednisolone were given $100 \mathrm{n}$ 
Table 1 Patients studied

\begin{tabular}{|c|c|c|c|c|c|c|}
\hline \multicolumn{3}{|c|}{$\begin{array}{l}\text { Those treated with }<5 \mathrm{mg} \\
\text { prednisolone/day, or with } \\
\text { nonsteroidal drugs only }\end{array}$} & \multicolumn{4}{|c|}{$\begin{array}{l}\text { Those treated with at least } 5 \mathrm{mg} \\
\text { prednisolone/day, or with } A C T H\end{array}$} \\
\hline $\begin{array}{l}\text { Specimen } \\
\text { no. }\end{array}$ & Sex & $\begin{array}{l}\text { Age } \\
(y r s)\end{array}$ & $\begin{array}{l}\text { Specimen } \\
\text { no. }\end{array}$ & $\operatorname{Sex}$ & $\begin{array}{l}\text { Age } \\
\text { (yrs) }\end{array}$ & $\begin{array}{l}\text { Duration of } \\
\text { therapy (yrs) }\end{array}$ \\
\hline 1029 & $\mathbf{M}$ & 60 & 1078 & $\mathrm{~F}$ & 59 & 4 \\
\hline$\{1052$ & $\mathbf{F}$ & 50 & $\int 1085$ & $\mathrm{~F}$ & 62 & 5 \\
\hline 1057 & & & $\{1089$ & & & \\
\hline $\int 1080$ & $\mathbf{F}$ & 58 & 1205 & $\mathrm{~F}$ & 65 & 5 \\
\hline$\{1084$ & & & 1267 & $\mathbf{M}$ & 78 & 3 \\
\hline $\int 1212$ & $\mathbf{F}$ & 43 & 1339 & $\mathrm{~F}$ & 29 & 2 (ACTH) \\
\hline 1213 & & & 1373 & $\mathbf{M}$ & 55 & 12 \\
\hline 1233 & $\mathbf{F}$ & 54 & 1445 & $F$ & 45 & 4 \\
\hline 1260 & $\mathbf{F}$ & 55 & 1462 & $\mathbf{F}$ & 69 & 3 \\
\hline 1345 & $\mathbf{F}$ & 48 & & & & \\
\hline 1430 & $\mathbf{F}$ & 46 & & & & \\
\hline 1503 & $\mathbf{F}$ & 35 & & & & \\
\hline 1510 & F & 50 & & & & \\
\hline
\end{tabular}

hydrocortisone with the premedication immediately before operation. In addition, 4 specimens of nonrheumatoid synovial tissue, obtained during routine arthrotomy for internal derangements, were used for in vitro studies.

Samples including the synovial lining, approximately $5 \times 3 \times 3 \mathrm{~mm}$, were chilled by precipitate immersion into $n$-hexane (B.D.H. 'free from aromatic hydrocarbon' grade, b.p. $67-70^{\circ} \mathrm{C}$ ) at $-70^{\circ} \mathrm{C}$ for up to $1 \mathrm{~min}$. They were then stored in a dry tube at this temperature for up to 3 days. Other specimens were cut into similar-sized pieces and maintained in vitro in Trowell (1959) maintenance culture for 20 hours (Poulter et al., 1970). Various concentrations of glucocorticoids were added to the Trowell T8 medium used for maintaining some of these specimens. Where water-insoluble steroids were used, these were dissolved in absolute ethyl alcohol and added to the T8 medium to achieve a final concentration of alcohol of less than $1 \%$. In such cases an equivalent concentration of alcohol was included in the control. At the end of the culture period the specimens were chilled and stored in the same way as the biopsy specimens.

\section{Methods}

The tissue was sectioned at $12 \mu \mathrm{m}$ in a Bright's cryostat with the cabinet temperature of $-25^{\circ} \mathrm{C}$ and the knife cooled by having its haft packed with solid carbon dioxide. The sections were tested by the methods of Chayen et al. (1973a) for the following activities: (i) for glucose 6-phosphate dehydrogenase activity (total generation of NADPH), or (ii) for maximal oxidation of NADPH, or (iii) for the amount of NADPH, generated within the section by glucose 6-phosphate dehydrogenase activity, which was oxidized by the cells. For (i) the intermediate hydrogen-carrier phenazine methosulphate (PMS) was included in the reaction medium. Other studies have shown that this quantitative cytochemical method yields the same amount of dehydrogenase activity as the more conventional biochemical estimation (Altman, 1972). For (ii) the substrate was exogenously added NADPH, while for (iii) it was glucose 6-phosphate and $\mathrm{NADP}^{+}$with no intermediate hydrogen-carrier so that the reduction of the tetrazolium salt, by endogenously formed NADPH, depended solely on the microsomal respiratory pathway of the cells themselves (Chayen et al., 1973b).

The reaction media contained $3 \mathrm{mg} / \mathrm{ml}$ of purified neotetrazolium chloride (Merck) in $0.05 \mathrm{M}$ glycyl glycine buffer, $\mathrm{pH} 8 \cdot 0$, containing $20 \% \mathrm{w} / \mathrm{v}$ polyvinyl alcohol (PVA: BO5/140; Wacker, Germany); $3 \mathrm{mM}$ $\mathrm{NADP}^{+}$and $5 \mathrm{mM}$ glucose 6-phosphate disodium salt (Boehringer); for measuring the dehydrogenase activity the medium also contained $0.2 \mathrm{mg} / \mathrm{ml}$ PMS (Sigma). Before use, the medium was saturated with nitrogen and equilibrated to $37^{\circ} \mathrm{C}$.

The end-product of these reactions was the highly coloured and precipitated formazan (reduced neotetrazolium chloride). This was measured in each of a number of synovial lining cells by means of a scanning and integrating microdensitometer.

\section{Results}

\section{REPRODUCIBILITY OF MEASUREMENTS}

Two specimens of synovial tissue were obtained from the joint in 5 subjects. The results (Table 2) give a measure of the sampling error which can occur between different parts of one synovial tissue. The mean value for all the readings from each specimen differed from the mean of all the readings (both specimens) by up to $\pm 19 \%$, with three of the values differing by less than $\pm 5 \%$. The reproducibility between serial sections taken from any one specimen

Table 2 Reproducibility of glucose 6-phosphate dehydrogenase activity (integrated extinction $\times 10^{3} /$ unit field per $10 \mathrm{~min})^{*}$ in different samples from the same joint

\begin{tabular}{llllr}
\hline $\begin{array}{l}\text { Specimen } \\
\text { no. }\end{array}$ & \multicolumn{2}{l}{ Section no. } & Mean & $\begin{array}{l}\text { Total variation } \\
\text { (as \% of mean })\end{array}$ \\
\cline { 2 - 3 } & 1 & 2 & & \\
\hline 1029 & 418 & 411 & 415 & 1 \\
1052 & 424 & 525 & 474 & 11 \\
1080 & 468 & 433 & 450 & 4 \\
1212 & 382 & 406 & 394 & 3 \\
1085 & 179 & 120 & 150 & 19 \\
\hline
\end{tabular}

* Activities in Tables 3-6 were also measured in this way. 
was investigated in 8 specimens (Table 3). The reproducibility was within $\pm 10 \%$; the standard error of the means of all readings was usually considerably better than this (as shown in Tables 4, 5, 6).

\section{EFFECT OF GLUCOCORTICOIDS IN VITRO}

In general the oxidative activities were well maintained after 20-hour maintenance culture (Table 4). In the nonrheumatoid tissue (Table 4) hydrocortisone at $10^{-4} \mathrm{M}$ concentration produced some depression of the glucose 6-phosphate dehydrogenase activity (tested with PMS). In specimen $1152,10^{-6} \mathrm{M}$ hydrocortisone produced no change but an appreciable effect was found with $10^{-5} \mathrm{~mol} / \mathrm{l}$. This effect of $10^{-4} \mathrm{M}$ hydrocortisone on this activity in synovial lining cells from rheumatoid joints was much more marked (Table 4). Some depression of activity was observed even at $10^{-6} \mathrm{~mol} / \mathrm{l}$ (specimen 1430). This depression of the dehydrogenase activity was mimicked to some extent by a small diminution in the rate of oxidation of the NADPH which was

Table 3 Reproducibility of the measurement of glucose 6-phosphate dehydrogenase activity in duplicate sections from the same specimen

\begin{tabular}{lllll}
\hline $\begin{array}{llll}\text { Specimen } \\
\text { no. }\end{array}$ & \multicolumn{2}{l}{ Section no. } & Mean & $\begin{array}{l}\text { Total variation } \\
\text { (as \% of mean) }\end{array}$ \\
\cline { 2 - 3 } & 1 & 2 & & \\
\hline 1067 & 214 & 212 & 213 & $0 \cdot 4$ \\
1085 & 173 & 184 & 178 & $3 \cdot 3$ \\
1116 & 218 & 187 & 203 & $7 \cdot 7$ \\
1135 & 109 & 100 & 104 & $4 \cdot 3$ \\
1212 & 397 & 366 & 382 & $4 \cdot 1$ \\
1213 & 405 & 334 & 370 & $9 \cdot 6$ \\
1233 & 384 & 454 & 419 & $8 \cdot 2$ \\
1445 & 416 & 498 & 457 & $8 \cdot 9$ \\
\hline
\end{tabular}

generated from this enzyme activity. However, the high residual activity of this enzyme makes it unlikely that this was rate-limiting. The diminution in oxidetion of exogenously added NADPH makes it mone likely that it was this microsomal respiratory pateway which was affected. However, these effects werere very small relative to the depression of the primagy dehydrogenase activity (production of NADPH the presence of PMS).

\section{EFFECT OF GLUCOCORTICOIDS IN VIVO}

In biopsies of rheumatoid synovia from patien treated only with various nonsteroidal anti-inflarematory drugs, the lowest activity of glucose 6-phos: phate dehydrogenase of the synovial lining cells w\$S 376 units; the values ranged up to 560 units (Tabge 5). Similar levels of activity were found in patients who had received 2.5 or $3 \mathrm{mg}$ prednisolone a daф, but one patient receiving $4 \mathrm{mg}$ a day did show some apparent suppression of this activity although the ability to oxidize NADPH (first 2 columns of Tabqe 5) remained unaltered, at least in these samples.

In contrast (with one exception), in patients receiving at least $5 \mathrm{mg}$ prednisolone a day or $\vec{\phi}$ units/day Acthar gel, the activity of glucose 6-phost phate dehydrogenase was never above 380 units most values being under 200 units of activis (Table 6). The ability to oxidize exogenously added NADPH (column 2, Table 6) did not show axy consistent response compared with that found for the other patients (Table 5).

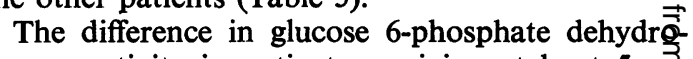
genase activity in patients receiving at least $5 \mathrm{mg}$ prednisolone a day, as against those receiving los than this dose (i.e. last column in Tables 5 and $: 6$ respectively) was highly significant $(\mathrm{P}<0 \cdot 001)$.

Table 4 Effect of glucocorticoids on synovial lining cells in vitro (mean $\pm S E M$ )

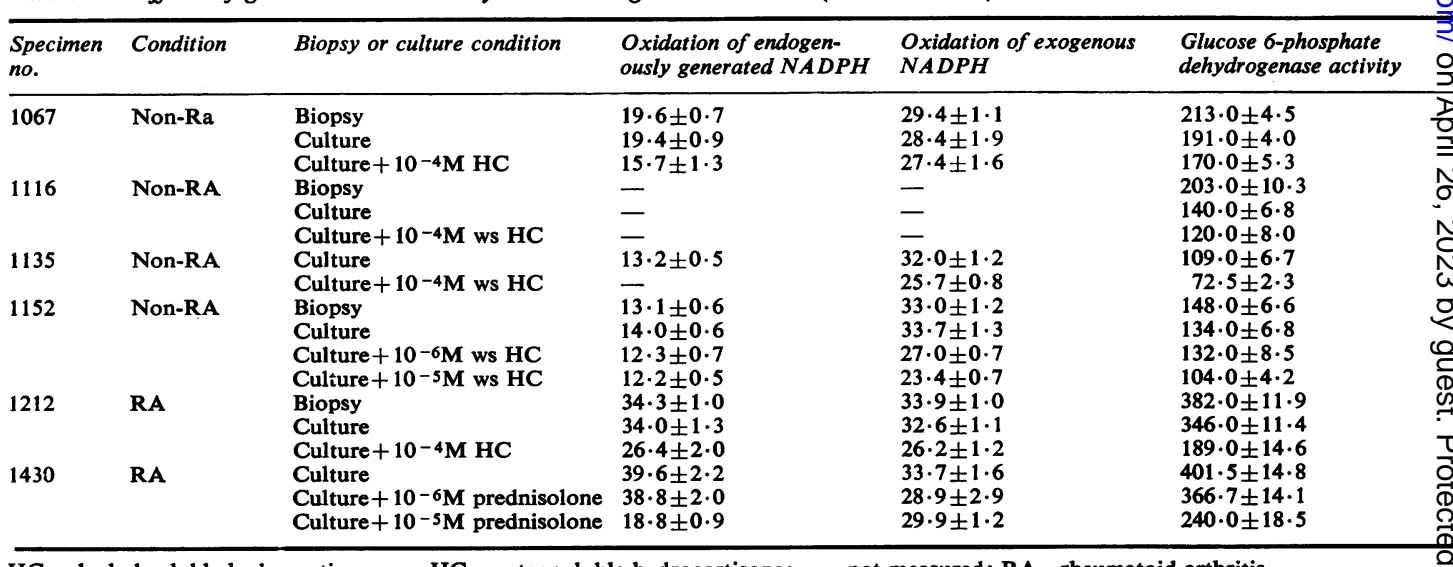

HC =alcohol-soluble hydrocortisone; ws $\mathbf{H C}=$ water-soluble hydrocortisone; $-=$ not measured; $\mathbf{R A}=$ rheumatoid arthritis. 
Table 5 Pentose-shunt oxidative activity (mean \pm SEM) in synovial lining cells of patients treated with $<5 \mathrm{mg}$ prednisolone/day

\begin{tabular}{|c|c|c|c|c|}
\hline $\begin{array}{l}\text { Specimen } \\
\text { no. }\end{array}$ & Treatment & $\begin{array}{l}\text { Oxidation of endogenously } \\
\text { generated NADPH }\end{array}$ & $\begin{array}{l}\text { Oxidation of exogenous } \\
\text { NADPH }\end{array}$ & $\begin{array}{l}\text { Glucose 6-phosphate } \\
\text { dehydrogenase activity }\end{array}$ \\
\hline $\begin{array}{l}1029 \\
1052 \\
1057 \\
1080 \\
1084 \\
1212 \\
1213 \\
1233 \\
1260 \\
1345 \\
1503 \\
1510\end{array}$ & $\begin{array}{l}\text { No steroids } \\
\text { No steroids } \\
\text { No steroids } \\
2 \cdot 5 \mathrm{mg} / \text { day prednisolone } \\
2 \cdot 5 \mathrm{mg} / \text { day prednisolone } \\
\text { No steroids } \\
\text { No steroids } \\
2 \cdot 5 \mathrm{mg} / \text { day prednisolone } \\
\text { No steroids } \\
4 \mathrm{mg} / \text { day prednisolone } \\
\text { No steroids } \\
\text { No steroids }\end{array}$ & $\begin{array}{l}23 \cdot 2 \pm 1 \cdot 0 \\
37 \cdot 2 \pm 1 \cdot 3 \\
46 \cdot 0 \pm 2 \cdot 0 \\
34 \cdot 7 \pm 0 \cdot 3 \\
34 \cdot 3 \pm 0 \cdot 3 \\
34 \cdot 3 \pm 1 \cdot 0 \\
38 \cdot 0 \pm 1 \cdot 3 \\
36 \cdot 7 \pm 7 \cdot 5 \\
34 \cdot 2 \pm 1 \cdot 3 \\
38 \cdot 0 \pm 1 \cdot 5 \\
-\end{array}$ & $\begin{array}{l}24 \cdot 4 \pm 1 \cdot 3 \\
33 \cdot 5 \pm 0 \cdot 8 \\
46 \cdot 2 \pm 0 \cdot 9 \\
34 \cdot 9 \pm 0 \cdot 3 \\
34 \cdot 1 \pm 0 \cdot 3 \\
33 \cdot 9 \pm 1 \cdot 0 \\
37 \cdot 0 \pm 1 \cdot 3 \\
36 \cdot 4 \pm 9 \cdot 1 \\
33 \cdot 5 \pm 1 \cdot 0 \\
35 \cdot 0 \pm 1 \cdot 1 \\
-\end{array}$ & $\begin{array}{l}418 \pm 14 \cdot 0 \\
424 \pm 14 \cdot 3 \\
525 \pm 10 \cdot 0 \\
471 \pm 5 \cdot 9 \\
432 \pm 14 \cdot 7 \\
382 \pm 9 \cdot 3 \\
376 \pm 15 \cdot 0 \\
419 \pm 12 \cdot 8 \\
444 \pm 15 \cdot 5 \\
230 \pm 7 \cdot 1 \\
560 \pm 9 \cdot 4 \\
535 \pm 10 \cdot 1 \\
481 \pm 11 \cdot 7 \\
438 \pm 65 \\
(\text { Mean } \pm \text { SD) }\end{array}$ \\
\hline
\end{tabular}

Table 6 Pentose-shunt oxidative activity (mean $\pm S E M)$ in synovial lining cells of patients treated with at least 5 mg prednisolone/day

\begin{tabular}{|c|c|c|c|c|}
\hline $\begin{array}{l}\text { Specimen } \\
\text { no. }\end{array}$ & Treatment & $\begin{array}{l}\text { Oxidation of endogenously } \\
\text { generated NADPH }\end{array}$ & $\begin{array}{l}\text { Oxidation of exogenous } \\
\text { NADPH }\end{array}$ & $\begin{array}{l}\text { Glucose 6-phosphate } \\
\text { dehydrogenase activity }\end{array}$ \\
\hline $\begin{array}{l}1078 \\
1085 \\
1089 \\
1205 \\
1267 \\
1339 \\
1373 \\
1445 \\
1462\end{array}$ & $\begin{array}{l}6 \mathrm{mg} / \text { day prednisolone } \\
\text { ", } \\
3 \mathrm{mg} \text { tds prednisolone } \\
\text { Acthar gel (Armour) } 8 \text { units/day } \\
6 \mathrm{mg} / \text { day prednisolone } \\
3 \mathrm{mg} \text { bd prednisolone } \\
5 \mathrm{mg} / \text { day prednisolone }\end{array}$ & $\begin{array}{l}43 \cdot 2 \pm 2 \cdot 4 \\
17 \cdot 2 \pm 1 \cdot 1 \\
13 \cdot 2 \pm 0 \cdot 5 \\
19 \cdot 8 \pm 0.8 \\
14 \cdot 3 \pm 0 \cdot 1 \\
22 \cdot 5 \pm 0.9 \\
20 \cdot 5 \pm 0.6 \\
\overline{16} \cdot 4 \pm 0.5\end{array}$ & $\begin{array}{l}47 \cdot 1 \pm 2 \cdot 4 \\
32 \cdot 6 \pm 1 \cdot 5 \\
35 \cdot 5 \pm 2 \cdot 1 \\
25 \cdot 0 \pm 1 \cdot 1 \\
30 \cdot 1 \pm 0 \cdot 3 \\
55 \cdot 0 \pm 1 \cdot 6 \\
20 \cdot 0 \pm 0 \cdot 7 \\
\overrightarrow{20} \cdot 0 \pm 0.3\end{array}$ & $\begin{array}{l}378 \pm 17 \cdot 3 \\
179 \pm 6 \cdot 3 \\
120 \pm 5 \cdot 5 \\
189 \pm 9 \cdot 4 \\
140 \pm 4 \cdot 2 \\
109 \pm 6 \cdot 0 \\
158 \pm 7 \cdot 4 \\
445 \pm 13 \cdot 4 \\
290 \pm 9 \cdot 0 \\
223 \pm 120 \\
(M e a \pm \text { SD) }\end{array}$ \\
\hline
\end{tabular}

\section{Discussion}

The synovial lining cells of rheumatoid joints differ from those of nonrheumatoid joints in two cellular biochemical aspects. The first is that the lysosomal membranes of the former are considerably more permeable than the latter as tested by quantitative cytochemical methods (Chayen et al., 1971; Chayen and Bitensky, 1971). This pertains even when the synovium is taken from recently traumatized joints in which the lysosomal permeability, as assessed by this test, is greater than in more quiescent joints (Chayen et al., 1971). The second is that the maximal rate of production of NADPH, from NADP, is between 3 and 4 times greater in the rheumatoid than in the nonrheumatoid lining cells(Butcher et al., 1973). It is well known that certain steroids, notably the glucocorticoids, may influence the permeability of membranes, particularly of lysosomes. Moreover, it has been shown that glucocorticoids administered in vivo exert some stabilizing influence on the lysosomes of the lining cells of the joints of rheumatoid patients treated with at least $5 \mathrm{mg}$ glucocorticoid per day (Bitensky et al., 1974). However, even though there is good evidence that steroids can influence the activity of purified glucose 6-phosphate dehydrogenase (Marks and Banks, 1960; Levy et al., 1966) and activity of the enzyme in certain tissues (Chayen $e t$ al., 1974), there has been no indication that glucocorticoids used in treating rheumatoid arthritis could influence this system.

Our results show that the administration of glucocorticoids to rheumatoid patients is associated with a depression of glucose 6-phosphate dehydrogenase activity, provided that at least $5 \mathrm{mg}$ prednisolone is given daily. At lower dosage the effect is indeterminate or not present. It must be borne in mind, however, that this threshold level may apply only to those joints with refractory disease since it is only these patients who come to synovectomy. For all that, it is of interest that Chamberlain and Keenan (1976) in a double-blind trial showed that patients receiving $3 \mathrm{mg}$ prednisolone/day sustained little clinical benefit whereas some clinical improvement was apparent in those treated with $5 \mathrm{mg} /$ day.

From the studies of Peterson and Wyngaarden (1956) it seems that steroids such as prednisolone become distributed throughout the extracellular 
body fluids. Consequently, taking the volume of these fluids as between 11 and 17 litres, $5 \mathrm{mg}$ prednisolone would achieve a concentration outside the tissues of roughly $10^{-6} \mathrm{~mol} / \mathrm{l}$. It is noteworthy that in the studies on synovial tissue maintained in vitro (Table 4) hydrocortisone appreciably depressed glucose 6-phosphate dehydrogenase activity when the hydrocortisone was present at a concentration of $10^{-5} \mathrm{~mol} / \mathrm{l}$. The longer time that prednisolone would act in vivo might account for this ten-fold difference in concentration required to achieve the same effect in vitro as in vivo. Moreover, the duration of glucocorticoid concentration in the body may also influence the effect. Thus in the patient (Table 6, specimen no. 1267) who received $3 \mathrm{mg}$ prednisolone three times a day glucose 6-phosphate dehydrogenase activity was only 140 units of activity, whereas in the patient (Table 6, specimen no. 1445) who received $3 \mathrm{mg}$ twice a day the activity was 445 units, comparable to the values found in Table 5. It may be noteworthy that treatment with Acthar gel (Table 6, specimen no. 1339) produced the lowest activity recorded for any rheumatoid specimen. Perhaps the efficacy of glucocorticoid therapy in depressing the high glucose 6-phosphate dehydrogenase activity found in rheumatoid synovial lining cells depends (a) on the level achieved at any one time, and (b) on the duration of the daily exposure to raised levels of the steroid.

The implication of these findings is that, in unit time, rheumatoid synovial lining cells are capable of producing up to 4 times as many reducing equivalents, associated with glucose 6-phosphate dehydrogenase and NADP in the cytosol, as the non-rheumatoid cells. Yet their rate of oxidation of endogenously or exogenously added NADPH is reasonably similar. One effect of glucocorticoids is to diminish this rate of production of reducing equivalents. However, it is evident that even a dose of $6 \mathrm{mg}$ /day does not depress the glucose 6-phosphate dehydrogenase activity to nonrheumatoid levels.

We are grateful to the Arthritis and Rheumatism Council for Research for its general support.

\section{References}

Altman, F. P. (1972). Quantitative dehydrogenase histochemistry with special reference to the pentose shunt dehydrogenases. Progress in Histochemistry and Cytochemistry, 4, 225-273.
Bitensky, L., Butcher, R. G., Johnstone, J. J., and Chaye@gJ. (1974). Effect of glucocorticoids on lysosomes in synowial lining cells in human rheumatoid arthritis. Annals of the Rheumatic Diseases, 33, 57-61.

Butcher, R. G., Bitensky, L., Cashman, B., and Chaye (1973). Differences in the redox balance in human rheumatoid and non-rheumatoid synovial lining cells. Beiträge $\frac{\text { जur }}{\mathrm{s}}$ Pathologie, 148, 265-274.

Chamberlain, M. A., and Keenan, J. (1976). The effec思 of low doses of prednisolone compared with placebo on the function and on the hypothalamic pituitary adrenal exis in patients with rheumatoid arthritis. Rheumatology $\overrightarrow{\text { fnd }}$ Rehabilitation, 15, 17-23.

Chayen, J., and Bitensky, L. (1971). Lysosomal enzymes $\overrightarrow{\overrightarrow{a n} d}$ inflammation with particular reference to rheuma@id diseases. Annals of the Rheumatic Diseases, 30, 522-53ఖ

Chayen, J., Bitensky, L., Butcher, R. G., and Cashman (1971). Evidence for altered lysosomal membraneso.in synovial lining cells from human rheumatoid joints. Beiträge zur Pathologie, 142, 137-149.

Chayen, J., Bitensky, L., and Butcher, R. G. (1970a). Practical Histochemistry. Wiley, London.

Chayen, J., Altman, F. P., and Butcher, R. G. (1973b). The effect of certain drugs on the production and possible utilization of reducing equivalents outside the mitochondria. Fundamentals of Cell Pharmacology, p. 196. \#d. by S. Dikstein. Thomas, Springfield, Illinois.

Chayen, J., Bitensky, L., Butcher, R. G., and Altman, F.P. (1974). Cellular biochemical assessment of steroid actiख்y. Advances in Steroid Biochemistry and Pharmacology $y^{4}$, $1-60$.

Levy, H. R., Raineri, R. R., and Nevaldine, B. H. (1966). On the structure and catalytic function of mamnary glucose 6-phosphate dehydrogenase. Journal of Biolo gifal Chemistry, 241, 2185-2187.

Marks, P. A., and Banks, J. (1960). Inhibition of mamma⿳⺈冂an glucose 6-phosphate dehydrogenase by steroids. Proceedings of the National Academy of Sciences of the USA, 76 , 447-452.

Peterson, R. E., and Wyngaarden, J. B. (1956). The miscible pool and turnover rate of hydrocortisone in man. Joungal of Clinical Investigation, 35, 552-561.

Poulter, L. W., Bitensky, L., Cashman, B., and Chayeญे J. (1970). The maintenance of human synovial tissue in vifro. Virchows Archives, Series B, 4, 303-309.

Ropes, M. W., Bennett, G. A., Cobb, S., Jacox, R., 娋n Jessar, R. A. (1959). Diagnostic criteria for rheuma\&oid arthritis. Annals of the Rheumatic Diseases, 18, 49.

Trowell, D. A. (1959). The culture of mature organs in a synthetic medium. Experimental Cell Research, 16 , 118-147.

Weissmann, G. (1968). Effect on lysosomes of drugs usefü in connective tissue disease. A Symposium on the Interation of Drugs and Subcellular Components in Animal Cells, p. 203. Ed. by P. N. Campbell. Churchill, London.

Weissmann, G. (1969). Effects of steroids and drugףion lysosomes. Lysosomes in Biology and Pathology, Vol. 1 , p. 276. Ed. by J. T. Dingle and H. B. Fell. North-Holliend, Amsterdam. 